\title{
IAMJ
}

INTERNATIONAL

AYURVEDIC

MEDICAL JOURNAL

ISSN: 2320-5091

Impact Factor: 6.719

\section{PHARMACEUTICAL STUDY OF MRIGANKARASA}

\author{
Syama Maniyankutty ${ }^{1}$, Gauthaman $\mathbf{M}^{2}$ \\ ${ }^{1}$ Assistant Professor, Department of Rasasastra and Bhaishajya Kalpana, Krishna Ayurveda Medical College, \\ Vadodara, Gujarat, India \\ ${ }^{2}$ Associate Professor, Department of Rasasastra and Bhaishajya Kalpana, MVR Ayurveda Medical College, \\ Parassinikadavu, Kerala, India
}

Corresponding Author: syaamaabhi@gmail.com

https://doi.org/10.46607/iamj0709032021

(Published online: March 2021)

Open Access

(C) International Ayurvedic Medical Journal, India 2021

Article Received: 20/02/2021 - Peer Reviewed: 24/02/2021 - Accepted for Publication: 05/03/2021

(A) Check for updates

\section{ABSTRACT}

Rasasastra is a branch which deals with medicinal properties of minerals and metals. According to the different process involved and shape of the product acharyas have classified rasaushadhis as Khalveeya rasa, Parpati, Pottali and Koopipakwa rasa. By the preparation of above mentioned rasaushadhis Acharyas mainly aimed to reduce the toxicity as well as the dosage. Many of these can act as emergency medicines. Increased global curiosity regarding the safety and efficacy of various metallic and mineral preparations in Rasasastra, there is an imminent need to pay attention to the establishment of Standard operating procedure (SOP) for producing good quality product by following certain parameters fixed after a number of experiments. Pharmaceutical study of Mriganka Rasa is an attempt to unfold the idea behind the technique used to prepare the drug. It is a metallic preparation described in Rasayogasagaram and Sidhabheshajamanimala in the kshaya prakaranam which contains mainly Vangam, Gandhaka, Navasara and saindhava lavanam. It is a koopipakwa preparation which is mainly indicated for all types of Prameha. Most of the koopipakwa rasas contain mercury as a main content. But in this preparation mercury is absent. Wide range of indications from Prameha to Dhatukshaya shows its efficacy. So, knowing its pharmaceutical and therapeutical importance the present study has been conducted. Methodology includes pharmaceutical study with observations and results. Pharmaceutical part of the study was conducted as per the textual reference of Rasayogasagaram. The average yield of gandhaka after shodhana was 291.33g, navasara 
was $485 \mathrm{~g}$, vanga was $140.83 \mathrm{~g}$, jaritha vanga was $119.66 \mathrm{~g}$, navasara saindhava satva was $112.66 \mathrm{~g}$ and that of the mrigankarasa was $50 \mathrm{~g}$

Keywords: Mriganka rasa, Koopipakwa rasa, Satvapatana, Jarana

\section{INTRODUCTION}

Rasaushadhis are a category of Ayurvedic formulations that has to be explored scientifically and therapeutically. Rasasastra is a branch which deals with medicinal properties of minerals and metals. According to the different process involved and shape of the product acharyas have classified rasaushadhis as Khalveeya rasa, Parpati, Pottali, Koopipakwa rasas etc. By the preparation of above mentioned $\mathrm{ra}$ saushadhis the Acharyas mainly aimed to reduce the toxicity as well as the dosage. In clinical practice the usage of rasaushadhis is increasing because of the shortage of herbal drugs, increased demand, multiple pathology and need for an instantaneous relief. Mriganka Rasa ${ }^{l}$ taken for the present study is a mineral preparation mentioned in Rasakaumudi and $\mathrm{Si}$ dhabheshajamanimala in kshaya prakarana and also in Rasayogasagaram. This is a kupipakva rasayana preparation in which parada is not an ingredient. This is prepared in a specially designed glass bottle covered with seven layers of mud smeared cloth, which is then heated over fire in a Valuka yantra and finally the product is collected from the base of the bottle. Various preparations by the name Mrigankarasa are available in different Rasa texts. But these differ in ingredients and indications from the Mrigankarasa that is taken for the present study. Thus, the present study "Pharmaceutical study of Mrigankarasa" is an attempt to unfold the idea behind the technique used to prepare the drug. The formulation has got a wide range of indications from Prameha to Dhatukshaya. Thus, the study was conducted for pharmaceutical standard and to get the therapeutic importance. The ingredients present in this formulation are Navasara, Saindhava, Vangam and Gandhakam. So, knowing its pharmaceutical and therapeutical importance the present study has been conducted

\section{Aim and Objective}

To develop standard product (Mrigankarasa) as per classical parameters.

\section{Materials and Method}

Developing a standard protocol is the major objective of the study. To achieve the aim apart from the conceptual study the pharmaceutical study was carried out, and all the findings dealt with this are being discussed here. The pharmaceutical study was carried out in 6 sections:-

1. Selection and collection of raw materials

2. Shodhana of individual drugs

3. Apamarga kshara nirmanam

4. Satvapatana

5. Vangajarana

6. Mrigankarasa nirmana

Selection of Raw Materials: The ingredients of this preparation like Gandhaka, Vanga, Navasara and Saindhava were selected on the basis of their grahya lakshnas mentioned in the classics. These drugs were collected from Kannur.

Shodhana of individual drugs with Observations and Results: This section includes 3 practicals.

Practical no 1: The practical number 1 deals with purification of Gandhaka. Gandhaka shodhana was carried out as per the reference from Ayurveda Pra$k a s h a^{2}$ where purification is done by Kurmaputa vidhi in Goksheeram. Three samples of Gandhaka were purified by this method. In this method Gandhaka which is spread over a cloth tied on the mouth of a mud pot containing milk which is covered by another same sized pot and sandhilepana done was subjected to kurma putam using 20 vanopala $(2189 \mathrm{~g})$. The maximum temperature reached was $250^{\circ} \mathrm{C}$. By this the impurities whose melting point above $250^{\circ} \mathrm{C}$ may remain stick on the surface of cloth without falling into the milk and the fat-soluble impurities were lost in the milk. For the 1 st sample it took $4.30 \mathrm{hrs}$ for complete 
burning and swangasheetam and for the remaining two samples it took only $4.20 \mathrm{hrs}$. For $1^{\text {st }}$ and $2^{\text {nd }}$ sample the maximum temperature $\left(200-250^{\circ} \mathrm{C}\right)$ remained for 20 minutes and that for $3^{\text {rd }}$ sample remained for 30 minutes. After shodhana there was a loss of $8 \mathrm{~g}$ (2.67\%) of Gandhaka for sample1 and 3 and a loss of $10 \mathrm{~g}(3.33 \%)$ for sample2. This loss of weight may be due to the loss of impurities present in the sulphur. But in all the three samples the yellow colour of Gandhaka turned to lemon yellow and the form was globular. This was powdered and used for the preparation of Mriganka rasa. The average yield of Gandhaka was 291.33g.

Practical No 2: Practical no2 deals with vanga shodhana by Dalana method. This method of purification was selected from Rasaratnasamucchaya ${ }^{3}$. Various methods of purification of vanga were described by various Acharyas but this method seems to be commonest and was selected for the study. Three samples of Vanga were purified by this method. In this method vanga was melted and poured into nirgundi swarasa mixed with haridra choornam through a Pithara yantra. This method was repeated for 3 times as per the reference. $150 \mathrm{~g}$ Vanga was taken for shodhana.350ml of nirgundi swarasa was required for a single dalana for the three samples. From $1500 \mathrm{~g}$ of fresh nirgundi patra $1050 \mathrm{ml}$ of swarasa was obtained and this was used for the three dalana process for a single sample. Haridra choorna was added in the quantity of $1 / 16^{\text {th }}$ part of vanga for each dalana according to Rasaratnasamucchaya.

For doing this procedure a specially designed yantra known as Pithara yantra was used. This yantra was designed according to the reference in $R a$ sayanasaram $^{8}$. It consists of an iron vessel with an iron lid. In the centre of the lid there is a small opening of $2.8 \mathrm{~cm}$ diameter. The melted vanga was poured through this small opening. In all the samples the vanga took only 2 minutes for completely melting and the melting point was found to be in the range of 218$225^{\circ} \mathrm{C}$. Flame temperature was maintained between 590-600 ${ }^{\circ}$ C.Ph of nirgundi swarasa containing haridra churnam was 5.88 before dalana. After $1^{\text {st }}$ dalana $\mathrm{pH}$ increased to 5.89 , after $2^{\text {nd }}$ dalana to 5.89 and to 5.98 after $3^{\text {rd }}$ dalana. This was almost similar for other two samples too. This change in $\mathrm{pH}$ shows that the swarasa became slightly alkaline after dalana.

After each dalana there was only slight loss in swarasa, which can be considered to be negligible. A blackish yellow coloured layer was seen on the surface of melted vanga, but after $1^{\text {st }}$ dalana the colour changed to black. These may be the impurities. During melting of vanga for $2^{\text {nd }}$ and $3^{\text {rd }}$ dalana, there was bursting sound heard, it may be due to some moisture content left back in the vanga after washing and drying. Melted vanga became solidified on pouring into swarasa and it may be due to sudden cooling. Processes like melting and sudden cooling have their own contribution in the purification of vanga. On heating only, the vanga melts and the impurities remain on the surface of molten vanga. These can be removed by washing in hot water. For $1^{\text {st }}$ sample a loss of $3 \mathrm{~g}$ was seen after $1^{\text {st }}$ dalana, a loss of $2 \mathrm{~g}$ after $2^{\text {nd }}$ dalana and a loss of $2.5 \mathrm{~g}$ after $3^{\text {rd }}$ dalana. So, in total a loss of 7.5 $\mathrm{g}$ was seen for sample 1 . For sample 2 and 3 a loss of $10 \mathrm{~g}$ was seen. This loss may be the loss of impurities and also the loss that happened during the time of washing and cleaning after each dalana. Thus, after shodhana, vanga became more brittle and the average yield was $140.83 \mathrm{~g}$.

Practical No 3: Practical no 3 deals with the purification of Navasara. This method of purification was selected from Rasatarangini ${ }^{4}$. As this was the commonest method adopted for Navasara shodhana, it was selected for the present study. Three samples of Navasara were purified by this method. In this method Navasara was dissolved in 3 times water, filtered and heated till completely dried. On adding water into the navasara the temperature inside the vessel got reduced to $9^{\circ} \mathrm{C}$, which shows its exothermic reaction. The dissolving time was 9 minutes for the three samples. Ph of plain water was 6.46 and it changed to 5.80 after dissolving the navasara. Thus, water became acidic after dissolving navasara. There was no change in colour for water after dissolving navasara. For all samples, it took $2.30 \mathrm{hrs}$ for completing the shodhana procedure. Also, within 15 minutes the solution started boiling. The boiling temperature range was 100- 
$106^{\circ} \mathrm{C}$. The temperature of vessel for $1^{\text {st }}$ sample was $77^{\circ} \mathrm{C}$, for $2^{\text {nd }}$ sample was $72^{\circ} \mathrm{C}$ and that for $3^{\text {rd }}$ sample was $82^{\circ} \mathrm{C}$. A white layer was seen on the surface of the solution after 50 minutes of boiling, for all the three samples. And after $1.20 \mathrm{hrs}$, the product turned semisolid and powdering started after $1.45 \mathrm{hr}$. Thus after $2.30 \mathrm{hr}$ complete powder form of navasara was obtained.500g each was taken for shodhana. There was a loss of $22 \mathrm{~g}$ of navasara for sample $1,13 \mathrm{~g}$ for sample 2 and $10 \mathrm{~g}$ for sample 3 . The average yield was $485 \mathrm{~g}$.

\section{Apamarga kshara nirmana}

A pilot study was done to compare the Vanga jarana using apamarga panchanga and apamarga kshara. 20 g of shodita Vanga was taken for each jarana. As per the reference 5 (RT) the apamarga panchanga required was only $1 / 4^{\text {th }}$ part of vanga ie, $5 \mathrm{~g}$. But it was found that about $350 \mathrm{~g}$ of apamarga panchanga was required to complete the procedure. In the second procedure of vangajarana only $5 \mathrm{~g}$ of apamarga kshara was enough to complete the procedure. In Agastya Vaidya Chandrika there is a reference which state that wherever the moolikas are mentioned the moolika kshara is used. Thus, on the basis of this reference and the above done pilot study it was decided to do vangajarana using apamarga kshara.

Practical no 4 deals with the Apamarga kshara nirmana. Apamarga kshara was prepared according to the reference from Sarangdhara Samhitha chap 11/104. Various references are available for apamarga kshara nirmana, but this reference seems to be simple and easy, thus was selected for the present study. Fresh apamarga was collected, dried and burned to ash. Then this ash was mixed with 4 times water and kept undisturbed for one night. Next morning the supernatant portion was decanted and filtered for 25 times to get a clear solution. This solution was heated till completely evaporated and the kshara was collected from the bottom of vessel. Only one sample was prepared.

$25 \mathrm{~kg}$ fresh Apamarga was collected. And after drying the weight got reduced to $8 \mathrm{~kg}$. On burning this, $680 \mathrm{~g}$ ash was obtained. This ash was added with 4 times water. From this ash $95 \mathrm{~g}$ of kshara was obtained.
It took only 25 minutes for completely burning the dry apamarga. The $\mathrm{pH}$ of ash was 9.97, which rose to 10.92 after $25^{\text {th }}$ filtration, showing that the alkalinity has increased. Also, Gomutra Varna clear solution was obtained after $25^{\text {th }}$ filtration.

Percentage yield from fresh apamarga was $0.38 \%$, from dry apamarga was $1.18 \%$ and that from burnt ash was $13.97 \%$.

\section{Vanga Jarana}

Practical no 5 deals with Vanga jarana. Vanga jarana was done according to the reference of Rasatarangini $^{6}$. Jarana is considered to be an intermediate procedure between shodhana and marana. Various methods are mentioned in Rasatarangini for vanga jarana. In the present study vanga jarana using apamarga was taken. Shodhita vanga was melted and added with apamarga $\left(1 / 4^{\text {th }}\right.$ part $)$ and stirred continuously till powder form was obtained.

Temperature of the iron vessel was maintained between $200-230^{\circ} \mathrm{C}$ for the three samples and the flame temperature was $600^{\circ} \mathrm{C}$. Powdering started after 45 minutes and within 2 hours vanga was completely powdered. After 4 hours the vessel became red hot and took another 4 hours to attain swangasheeta. This was almost same for all the three samples.

$100 \mathrm{~g}$ of vanga was taken for each jarana process and $25 \mathrm{~g}$ of apamarga kshara was added for each jarana procedure. For sample 1 there was a gain of $17 \mathrm{~g}$, for sample 2 a gain of $22 \mathrm{~g}$ and for sample 3 a gain of $20 \mathrm{~g}$. This weight gain may be due to the addition of apamarga kshara. The average yield of vanga choornam was $119.66 \mathrm{~g}$.

\section{Satvapatana}

Practical no 6 deals with the Navasara Saindhava satvapatana. This was done according to the reference of Rasayogasagaram. Here both Shodhita Navasara and Saindhava was taken $240 \mathrm{~g}$ ( 5 palam) each as per the reference and subjected to satvapatana in a Damaru yantra for 12 hours. The yellowish flower like satva was collected from the upper pot.

On mixing navasara and saindhava the consistency remained the same, but there was odour of ammonia. About $126 \mathrm{~g}$ satva was obtained from $1^{\text {st }}$ sample, $112 \mathrm{~g}$ 
from $2^{\text {nd }}$ sample and $100 \mathrm{~g}$ from $3^{\text {rd }}$ sample. The average yield of satva was $112.66 \mathrm{~g}$.

\section{Mrigankarasa nirmana}

Practical no 7 deals with the preparation of Mrigankarasa. This was carried out according to the reference from Rasayogasagara ${ }^{7}$. As per this reference first Navasara Saindhava satva has to be prepared, that has been already discussed. Then this satva has to be mixed with equal quantity of vanga choorna and finally with Gandhaka choornam (quantity equal to the above mixture). This mixture was filled into the $\mathrm{ka}$ chakupi and subjected to heating in a valuka yantra for 36 hours as per the reference. Vanga churnam was added into Navasara Saindhava satva and mardana done for 2 hours, a light grey coloured smooth powder was obtained. During mixing it emitted the smell of ammonia. And later on, to this mixture the Shodhita Gandhaka churnam was added and again mardana done for 2hours. After mixing with gandhaka a greyish green coloured smooth powder was obtained. For the three samples the sand became hot after one hour of heating when the temperature reached $220^{\circ} \mathrm{C}$. After 2hours of heating when the temperature has reached $250^{\circ} \mathrm{C}$ there was appearance of fumes inside the bottle with an emission of foul smell similar to the smell of rotten egg. During the preparation of $1^{\text {st }}$ sample, after 30 hours of heating when the temperature was raised to $600^{\circ} \mathrm{C}$, gandhaka started bursting out of the bottle along with flame on the mouth and this lasted for 30 minutes and then the temperature was lowered to $500^{\circ} \mathrm{C}$, as a result of which the flame along the mouth subsided and the bursting out of gandhaka also have stopped. Then until 36 hours the temperature was maintained between $500-550^{\circ} \mathrm{C}$. Since because of this for the next two samples temperature was maintained below $600^{\circ} \mathrm{C}$. For sample 2 the maximum temperature reached was 550 and for sample 3 it was $580^{\circ} \mathrm{C}$. After 36 hours of heating, when the fumes got subsided corking was done. And after swangasheeta kupi was taken out of the valuka yantra. The colour of kapadamitti was light black. For $1^{\text {st }}$ sample the weight of Mrigankarasa obtained was $52.5 \mathrm{~g}$, for sample 2 it was $50 \mathrm{~g}$ and for sample 3 it was $68 \mathrm{~g}$. The percentage weight loss for sample 1 was $72 \%$, for sample 2 was $44 \%$ and that for sample 3 was $54 \%$. This weight loss may be due to the escape of free sulphur in the form of fumes.

Table 1: Showing the result of Mrigankarasa

\begin{tabular}{|l|l|l|l|}
\hline Features & Sample 1 & Sample 2 & Sample 3 \\
\hline Weight before & $300 \mathrm{~g}$ & $300 \mathrm{~g}$ & $300 \mathrm{~g}$ \\
\hline Weight of final product & $52.5 \mathrm{~g}$ & $50 \mathrm{~g}$ & $68 \mathrm{~g}$ \\
\hline Residue & $25 \mathrm{~g}$ & $60 \mathrm{~g}$ & $49 \mathrm{~g}$ \\
\hline Neck deposits & $6 \mathrm{~g}$ & $58 \mathrm{~g}$ & $20 \mathrm{~g}$ \\
\hline Total fuel used & $100 \mathrm{~kg}$ & $100 \mathrm{~kg}$ & $100 \mathrm{~kg}$ \\
\hline Rekha purnatha & + & + & + \\
\hline
\end{tabular}

Table 2: Showing classical physico chemical parameters of final product

\begin{tabular}{|l|l|}
\hline Parameters & Features \\
\hline Varna & Swarnabha varna \\
\hline Sparsha & Smooth \\
\hline Gandha & Characteristic \\
\hline Rasa & Lavana \\
\hline Rekhapurnatha & + \\
\hline
\end{tabular}

\section{DISCUSSION}

Mriganka rasa is a koopipakwa rasayana preparation which has got a wide range of indications. The present study was done to develop an SOP for Mriganka rasa and thereby exploring the various pharmaceutical procedures carried out for its preparation. Pharmaceutical 
procedures like shodhana, jarana, satvapatana, kshara nirmana and finally kupipakwarasa nirmana were carried out to obtain the final product. All the procedures were carried out according to the textual references for three times. Only slight variations were noticed in the quantity and quality of the products. After shodhana there was a loss of $8 \mathrm{~g}(2.67 \%)$ of Gandhaka for sample1 and 3 and a loss of $10 \mathrm{~g}$ (3.33\%) for sample2. This loss of weight may be due to the loss of impurities present in the sulphur. During Vanga shodhana for the $1^{\text {st }}$ sample a loss of $3 \mathrm{~g}$ was seen after $1^{\text {st }}$ dalana, a loss of $2 \mathrm{~g}$ after $2^{\text {nd }}$ dalana and a loss of $2.5 \mathrm{~g}$ after $3^{\text {rd }}$ dalana. So, in total a loss of 7.5 $\mathrm{g}$ was seen for sample 1 . For sample 2 and 3 a loss of $10 \mathrm{~g}$ was seen. This loss may be the loss of impurities and also the loss that happened during the time of washing and cleaning the vanga after each dalana. Thus, after shodhana vanga became more brittle. After navasara shodhana there was a loss of $22 \mathrm{~g}$ of navasara for sample 1, $13 \mathrm{~g}$ for sample 2 and $10 \mathrm{~g}$ for sample 3. The average yield of navasara was $485 \mathrm{~g}$. After burning the dry apamarga, the $\mathrm{pH}$ of ash was 9.97, which rose to 10.92 after $25^{\text {th }}$ filtration, showing that the alkalinity has increased. Also, Gomutra Varna clear solution was obtained after $25^{\text {th }}$ filtration. Percentage yield from fresh apamarga was $0.38 \%$, from dry apamarga was $1.18 \%$ and that from burnt ash was $13.97 \%$. After vanga jarana for sample 1 there was a gain of $17 \mathrm{~g}$, for sample $2 \mathrm{a}$ gain of $22 \mathrm{~g}$ and for sample 3 a gain of $20 \mathrm{~g}$. This weight gain may be due to the addition of apamarga kshara. The average yield of vanga choornam was $119.66 \mathrm{~g}$. For satvapatana, on mixing navasara and saindhava the consistency remained the same, but there was odour of ammonia. About $126 \mathrm{~g}$ satva was obtained from $1^{\text {st }}$ sample, $112 \mathrm{~g}$ from $2^{\text {nd }}$ and $100 \mathrm{~g}$ from $3^{\text {rd }}$ sample. The average yield of satva was $112.66 \mathrm{~g}$. For $1^{\text {st }}$ sample the weight of Mrigankarasa obtained was $52.5 \mathrm{~g}$, for $2^{\text {nd }}$ it was $50 \mathrm{~g}$ and for $3^{\text {rd }}$ it was $68 \mathrm{~g}$. The percentage weight loss for sample 1 was $72 \%$, for sample 2 was $44 \%$ and that for sample 3 was $54 \%$. This weight loss may be due to the escape of free sulphur in the form of fumes.

\section{CONCLUSION}

Due to changed global scenario it is necessary that certain updating and revalidation should be incorporated in Ayurvedic drug manufacturing sequence. Standards and specification which were present in olden days were sufficient to compete with time need but nowadays there is necessity to improve them to fulfil the norms of Quality Control and Standardisation, those which are must in this nuclear era. There is a wide scope for standardisation aspects of Kupipakva rasayana kalpana regarding the ingredients, their proportion, regarding the equipments, heating devices, fuel to be used, duration of heating, heating schedule, method of formulation etc. The formulation Mrigankarasa is specified in the treatment of sarvameha in the textbook of rasasastra. This unique formulation is mentioned in the textbooks like Rasakaumudi, Sidhabhaishajya manimala, and Rasayogasagaram. And the reference given in the second volume of $R a$ sayogasagaram was taken for the present study. This study was an attempt to develop an SOP for Mrigankarasa. The product Mrigankarasa could be successfully prepared by this method. The temperature pattern, yield and other observations were noted and discussed. Pharmaceutical study deals with the collection of drugs, their shodhana, Apamarga ksharanirmana, jarana of vanga, satvapatana of navasara and saindhava and finally the preparation of Mrigankarasa. Thus, a standard protocol was able to develop after this study.

\section{REFERENCES}

1. Sri Vaidya Pandit Hariprapannaji, Rasayogasagaram, Chowkhamba Krishnadas Academy, Varanasi, vol 2 page 177

2. Acharya sri Madhava, AP, Edited by Shri Gulraja Sharma Misra, Varanasi, chaukhamba bharati academy, 1965, chap2 page 257

3. Rasa vaghbhata, rasaratna samucchaya, edited by Dattatreya Ananthakulkari, New Delhi, Meharchand Lchmandas publications, reprint 2010, Sutrastana, chap 5, shloka 156, page124.

4. Acharya Sadananda Sharma, Rasa Tarangini, Translated by Shri Kasinath Shastri, Motilal Banarasidas, New Delhi, $11^{\text {th }}$ edition, reprint, 2004,14/3, p-326 
5. Pandit Sarangdharaacharya, Sarangdhara Samhith, edited by Pandit Parasurama Sastri, Vidyasgar, New Delhi, Chaukhamba Publication, Reprint 2013, madyamakhandam, 11 chap, 101shloka.

6. Sadananda Sharma, Rasatarangini, edited by Kashinatha shastry, Delhi, Motilal Banarasidas, $8^{\text {th }}$ edition, 2014, 18 chap, 19 shloka, page439.
7. Sri Vaidya Pandit Hariprapannaji, Rasayogasagaram, Chowkhamba Krishnadas Academy, Varanasi, vol 2 page 177

8. Pandit Shyama sundara AcharyaVaisya, Rasayanasara, Chaukhamba Krishnadas Academy, Varanasi,7th edition, 2005,vol 1, Dhatu shodhana marana prakarana,shloka117,p 231.

\section{Pictures of Mrigankarasa}

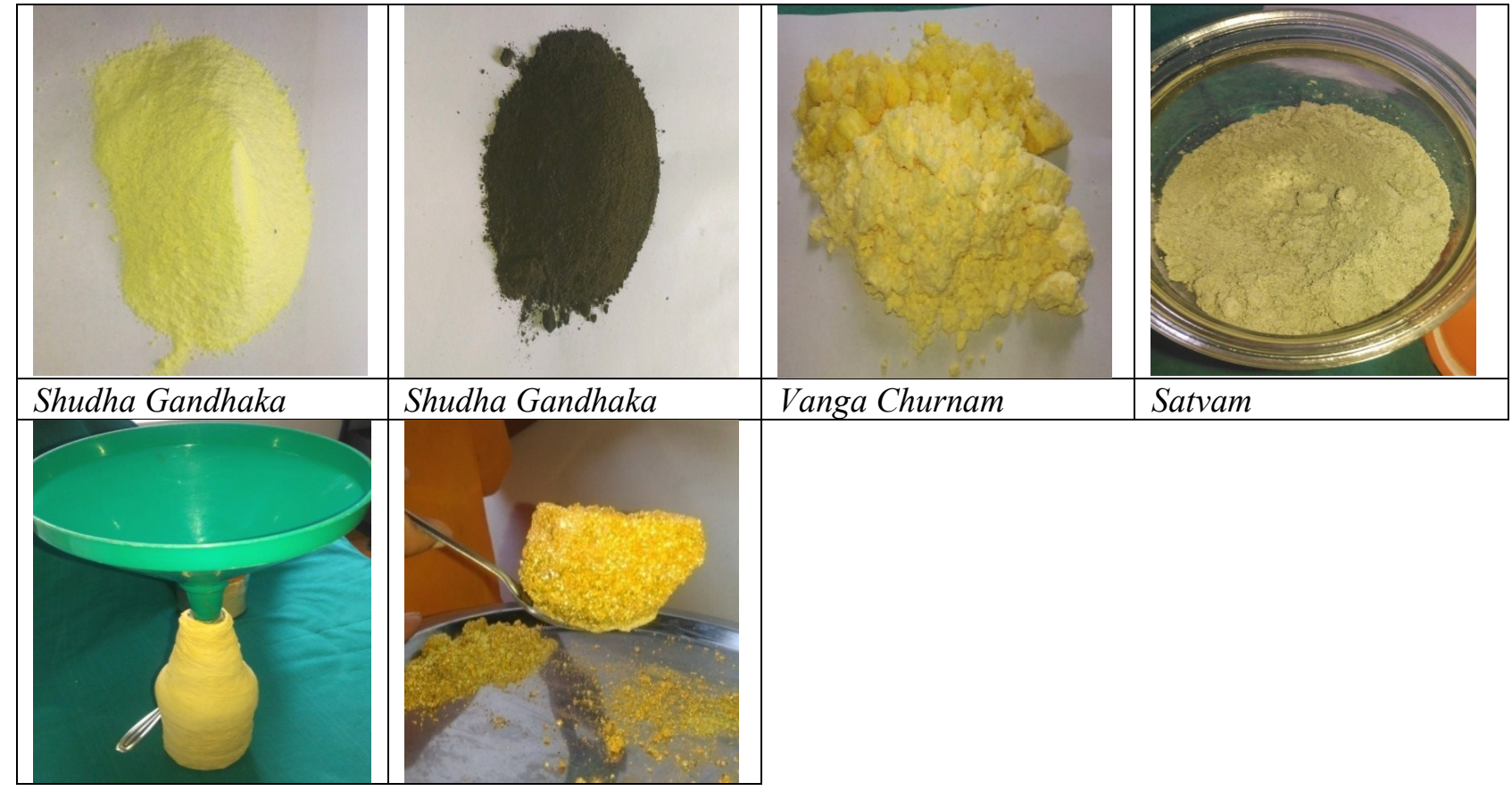

\section{Source of Support: Nil}

\section{Conflict of Interest: None Declared}

How to cite this URL: Syama Maniyankutty \& Gauthaman M: Pharmaceutical Study of Mrigankarasa. International Ayurvedic Medical Journal \{online\} 2021 \{cited March, 2021\} Available from: http://www.iamj.in/posts/images/upload/555 561.pdf 